\section{Conventional Citrus of Some Scion/ Rootstock Combinations Show Field Tolerance under High Huanglongbing Disease Pressure}

\author{
Ed Stover ${ }^{3}$, Sharon Inch', Matthew L. Richardson', and David G. Hall \\ USDA, ARS, U.S. Horticultural Research Laboratory, 2001 South Rock \\ Road, Fort Pierce, FL 34945
}

Additional index words. citrus breeding, citrus greening, disease resistance, grapefruit, HLB, mandarin hybrid, sweet orange

\begin{abstract}
The citrus disease huanglongbing (HLB) has become endemic in Florida, with estimates that greater than $80 \%$ of citrus trees are currently infected. Although there are no commercial citrus varieties with strong HLB resistance, some field tolerance has been observed in trees exposed to the disease after they were mature. There is great urgency to identify citrus which may permit economic citrus production where HLB is endemic. Therefore, the objective of this study was to assess field tolerance to HLB. To expedite the trial due to urgency, nursery trees were purchased on rootstock varieties as available. The trial included the following unbalanced scion/rootstock combinations: 'Hamlin/ Kinkoji', 'Hamlin/Cleopatra', 'Temple/Cleopatra', 'Fallglo/Kinkoji', 'Sugar Belle/Sour Orange', 'Tango/Kuharske', and 'Ruby Red/Kinkoji', with most comparisons based solely on scion/rootstock combinations. A randomized complete block experiment was established at Fort Pierce, FL, in Sept. 2010. All trees exhibited symptoms of HLB and tested positive for the Candidatus Liberibacter asiaticus (CLas) bacterium by Oct. 2012, with similar titers [directly assessed as cycle threshold $(\mathrm{Ct})$ using quantitative polymerase chain reaction (qPCR)] measured for all scion/rootstocks at most sample dates, but early titer development in 'Ruby Red/Kinkoji' was significantly lower than several other scion/rootstocks. Across all time-points, 'Fallglo/Kinkoji' had the lowest rating of distinctive HLB mottling and 'Ruby Red/Kinkoji' had the highest rating, but 'SugarBelle/Sour Orange' had the highest percentage of leaves affected. After 5 years, 'SugarBelle/Sour Orange' and 'Tango/Kuharske' had the greatest overall increase in trunk diameter, and were among the healthiest in overall appearance. In Oct. 2015, 'SugarBelle/Sour Orange' and 'Tango/Kuharske' trees had significantly greater fruit load (80-88 fruit/tree) followed by 'Temple/Cleopatra' and 'Fallglo/Kinkoji' (31-35 fruit/tree) while 'Hamlin/Kinkoji', 'Hamlin/Cleopatra', and 'Ruby Red/Kinkoji' produced less than 20 fruit per tree. Despite becoming infected by CLas in less than 2 years after planting, the trees continued to grow and all scion/rootstocks displayed increasing fruit production, although very low in 'Hamlin/Kinkoji', 'Hamlin/Cleopatra', and 'Ruby Red/Kinkoji'. Growth and fruit production in the highest performing scion/ rootstocks were likely less than would be expected for healthy trees, but these results are promising, with markedly better response of some scion/rootstocks with mandarin hybrid scions compared with trees with sweet orange or grapefruit scions. Larger fully replicated trials are underway. It is noteworthy that the most pronounced HLB symptoms and higher early pathogen titer, which are the two criteria most widely used in assessing HLB resistance, were not associated with the lowest growth and cropping, and focus on early symptomatic traits when screening for resistance may obscure important disease tolerance.
\end{abstract}

The citrus disease HLB has become endemic in Florida. HLB in Florida is associated with the phloem-limited bacterium CLas, which is vectored by the asian citrus psyllid (ACP) (Diaphorina citri) (Bové, 2006; Hall et al., 2013b). It is estimated that greater than $80 \%$ of Florida citrus trees are currently infected with CLas (Singerman, 2015), with many displaying marked declines in production, increases in fruit drop, and somewhat reduced fruit quality. Sweet orange and grapefruit, which constitute $>95 \%$ of Florida citrus production, appear to be especially compromised by HLB. Largely as a result, Florida citrus production in 2014-15 was the lowest it has been in 50 years (NASS, 2015). Of interest is that some mandarin hybrid cultivars appeared to have substantial tolerance to HLB when trees were exposed to the disease after maturity (Stover and McCollum, 2011; Stover et al., 2015). If tolerance is verified, through sustained growth and economic fruit production when newly planted trees are exposed, it is possible that some Florida citrus growers could opt to transition away from traditional sweet orange and grapefruit cultivars. Therefore, the objective of this study was to assess tolerance to HLB under field conditions of some scion/rootstocks to gain inferences about possible HLB tolerance.
Although a replicated, full factorial of standards and putatively tolerant scions each on the same rootstock would have been ideal, when this research was started there was no source of scions on the same rootstock and it would have taken several years to generate such plants. However, the following scion/ rootstock combinations were available from commercial nurseries: 'Temple/Cleopatra', 'Fallglo/Kinkoji', 'Sugar Belle/Sour Orange', 'Tango/Kuharske', Hamlin/Kinkoji', 'Hamlin/Cleopatra', and 'Ruby Red/Kinkoji'. The trees (HLB free) were purchased and a randomized complete block experiment was established. Ten trees of each of the seven combinations were regularly treated with imidacloprid, to try to control the insect vector to delay HLB, and ten additional trees of five combinations ('Hamlin/Kinkoji', 'Hamlin/Cleopatra', 'Temple/Cleopatra', 'Fallglo/Kinkoji', and 'Ruby Red/Kinkoji') were left untreated (only 10 trees of 'Sugar Belle/Sour Orange' and 'Tango/Kuharske' were available and all were treated with imidacloprid). This experiment is accurately viewed as comparing specific scion/rootstock combinations rather than scions alone and was essentially two overlapping experiments, one in which all imidacloprid trees were compared and another in which scion/rootstock combinations were compared with and without imidacloprid treatment.

The trial included 20 trees each of 'Hamlin/ Kinkoji', 'Hamlin/Cleopatra', 'Temple/ Cleopatra', 'Fallglo/Kinkoji', and 'Ruby Red/Kinkoji' with 10 imidacloprid-treated and 10 nontreated trees of each scion/ rootstock randomized within each of 10 blocks. An additional 10 trees each of 'Sugar Belle/ Sour Orange' and 'Tango/Kuharske' were included, one tree of each per block and all receiving imidacloprid. Trees were planted at the U.S. Department of Agriculture research farm, Fort Pierce, FL, in Aug. 2010 on tworow beds typical of the Indian River area, with $6.9 \mathrm{~m}$ between rows and $1.5 \mathrm{~m}$ between trees within a row. Trees not included in the experiment were planted at the ends of rows. This site was Ankona sand and trees were irrigated using microsprinklers that delivered shallow well water of $\mathrm{pH} 7.2$ and $240 \mathrm{mg} \cdot \mathrm{L}^{-1} \mathrm{CaCO}_{3}$ equivalents from a large bladder reservoir (47 million L), which minimizes seasonal variation in water quality.

Except for inclusion of enhanced foliar nutritional treatments that are widely used on HLB-affected blocks (Spann et al., 2014), all cultural practices were consistent with typical Florida production of processing citrus before the introduction of HLB. Details of cultural practices were as follows. Fertilization was applied twice each year to the soil. Hand fertilization occurred from planting with $0.3-0.5 \mathrm{~kg} /$ tree of slow release $13 \mathrm{~N}-$ 4P-9K. In Aug. 2013, ground broadcast of $336 \mathrm{~kg} \cdot \mathrm{ha}^{-1}$ of $12 \mathrm{~N}-2 \mathrm{P}-12 \mathrm{~K}$ plus $3 \% \mathrm{Mg}$ was used. In Mar. 2014, ground broadcast was increased to $449 \mathrm{~kg} \cdot \mathrm{ha}^{-1}$ of $12 \mathrm{~N}-2 \mathrm{P}-14 \mathrm{~K}$ 
Table 1. Huanglongbing (HLB) symptoms and pathogen titer [as cycle threshold ( $\mathrm{Ct}$ )] for seven rootstock/scion combinations in which 10 trees of each received imidacloprid three times per year. Trees were planted in Aug. 2010, at the U.S. Department of Agriculture research farm, Fort Pierce, FL, under high HLB disease pressure.

\begin{tabular}{|c|c|c|c|c|}
\hline Scion/Rootstock & Mean liberibacter titer $(\mathrm{Ct})^{\mathrm{z}}$ & Mean blotchy mottle rating ${ }^{y}$ & Mean yellow shoot rating ${ }^{y}$ & Mean rugose leaf rating ${ }^{y}$ \\
\hline Fallglo/Kinkoji & $22.0 \mathrm{a}^{\mathrm{x}}$ & $1.1 \mathrm{e}$ & $1.2 \mathrm{bc}$ & $1.0 \mathrm{~d}$ \\
\hline Hamlin/Cleopatra & $21.3 \mathrm{a}$ & $1.6 \mathrm{bcd}$ & $1.1 \mathrm{~cd}$ & $1.4 \mathrm{~b}$ \\
\hline Hamlin/Kinkoji & $21.3 \mathrm{a}$ & $1.5 \mathrm{~cd}$ & $1.1 \mathrm{~cd}$ & $1.3 \mathrm{~b}$ \\
\hline Ruby Red/Kinkoji & $22.6 \mathrm{a}$ & $2.1 \mathrm{a}$ & $1.5 \mathrm{a}$ & $2.3 \mathrm{a}$ \\
\hline SugarBelle/SO & $21.0 \mathrm{a}$ & $1.8 \mathrm{~b}$ & $0.9 \mathrm{~d}$ & $1.0 \mathrm{~cd}$ \\
\hline Tango/Kuharske & $21.1 \mathrm{a}$ & $1.4 \mathrm{~d}$ & $1.1 \mathrm{c}$ & $1.1 \mathrm{~cd}$ \\
\hline Temple/Cleopatra & $21.3 \mathrm{a}$ & $1.7 \mathrm{bc}$ & $1.3 \mathrm{bc}$ & $1.0 \mathrm{c}$ \\
\hline
\end{tabular}

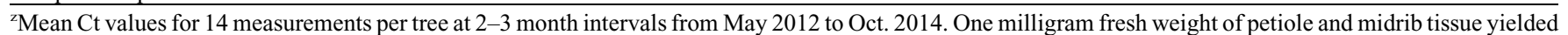
$\approx 1 \mathrm{ng}$ DNA. The following are calculated numbers of Candidatus Liberibacter asiaticus (CLas) genomes per ng DNA extracted: Ct of $21=3,290$ CLas genomes, $\mathrm{Ct}$ of $21.1=3,090$ CLas genomes, Ct of 21.3 = 2,730 CLas genomes, Ct of $22=1,756$ CLas genomes, and Ct of 22.6 = 1,204 CLas genomes.

${ }^{\mathrm{y}}$ Mean disease symptom severity over entire experiment as assessed on a 4-point scale for mottle $(0=$ healthy, $1=$ pale mottling, $2=$ mottle but symmetric, and $3=$ blotchy mottle), yellow shoot $(0=$ healthy green, $1=$ slightly pale, $2=$ yellow, and $3=$ very yellow $)$, and rugose leaves $(0=$ healthy, $1=$ slightly leathery, $2=$ fairly leathery, and 3 = very leathery), with trees scored by presence of the most severe symptoms on the tree for each category.

${ }^{x}$ Within a column, means followed by the same letter are not statistically significant at $P=0.05$.

plus $2.5 \% \mathrm{Mg}$. In Feb. 2015, ground broadcast was increased to $561 \mathrm{~kg} \cdot \mathrm{ha}^{-1}$ of $12 \mathrm{~N}-2 \mathrm{P}-$ $14 \mathrm{~K}$ plus $2 \% \mathrm{Mg}$.

Trees were sprayed 24 times per year (every $14 \mathrm{~d}$ ) with a low volume foliar application of $9.4 \mathrm{~L} \cdot \mathrm{ha}^{-1}$ of 435 spray oil, $4.5 \mathrm{~kg} \cdot \mathrm{ha}^{-1}$ of $20 \mathrm{~N}-10 \mathrm{P}-20 \mathrm{~K}$ complete greenhouse grade soluble fertilizer, and copper at 200 ppm (Magna-Bon LLC, Okeechobee, FL). Four times per year, with two sprays each timed to coincide with spring and summer flush, $\mathrm{Ca}, \mathrm{Mg}$, and $\mathrm{Fe}$ were added to the $20 \mathrm{~N}-10 \mathrm{P}-20 \mathrm{~K}$. Foliar fertilization was supplemented three times per year with 9.4 $\mathrm{L} \cdot \mathrm{ha}^{-1}$ of N-sure 28-0-0 (Tessenderlo Kerley, Phoenix, AZ) and two times per year with KeyPlex 1400 (KeyPlex, Winter Park, FL) at $4.7 \mathrm{~L} \cdot \mathrm{ha}^{-1}$.

Imidacloprid (Macho 2.0; Albaugh, LLC, Ankeny, IA) was applied at $1.89 \mathrm{~mL} /$ tree/ application in $240 \mathrm{~mL}$ water, three times per year from late March to late September. This was the labeled rate for trees at a commercially typical 210-420 trees/ha, even though experimental trees were at 919 trees/ha.

Tree height, canopy width, trunk diameter, fruit number, HLB phenotypic symptoms, and tree mortality were assessed monthly to quarterly beginning 20 months after planting. Tree canopy volume (TCV) was assessed using the assumption that tree shape was one-half a prolate spheroid

Received for publication 13 Nov. 2015. Accepted for publication 7 Jan. 2016.

This work was funded in part by the Citrus Research and Development Foundation.

The technical assistance of Stephen Mayo, Ellen Cochrane, Sean Reif, David Peabody, Diane Helseth, and Jonathan Worton is gratefully acknowledged.

Mention of trade names or commercial products in this article is solely for the purpose of providing specific information and does not imply recommendation or endorsement by the U.S. Department of Agriculture. USDA is an equal opportunity provider and employer.

${ }^{1}$ Current affiliation: Novozymes North America, Franklinton, NC.

${ }^{2}$ Current affiliation: University of the District of Columbia, CAUSES, 4200 Connecticut Avenue, Northwest, Washington, D.C. 20008.

${ }^{3}$ Corresponding author. E-mail: ed.stover@ars.usda.gov.
$(\mathrm{TCV}=4 \pi / 6 \times \mathrm{H} \times \mathrm{W} 1 \times \mathrm{W} 2)$. Disease symptom severity was assessed on a 4-point scale for mottle $(0=$ healthy, $1=$ pale mottling, $2=$ mottle but symmetric, and $3=$ blotchy mottle), yellow shoots $(0=$ healthy green, $1=$ slightly pale, $2=$ yellow, and $3=$ very yellow), and rugose leaves $(0=$ healthy, 1 = slightly leathery, 2 = fairly leathery, and $3=$ very leathery), with each tree scored based on the most severe symptoms on the tree for each category. In Feb. and Oct. 2015, trees were also scored for percentage of leaves displaying blotchy mottle. The number of fruit per tree was assessed in Nov. 2014 and Oct. 2015.

Monthly to quarterly, we also collected three of the most symptomatic leaves from each tree for qPCR. All leaf samples were stored at $-4{ }^{\circ} \mathrm{C}$ until processed. For each tree, the lower $2 \mathrm{~cm}$ from the leaf petiole base into the midrib were pooled. Each pooled sample was macerated in a Fast Prep 24 (MP Biomedicals, Santa Ana, CA) with DNA extracted from $200 \mathrm{mg}$ of macerated tissue using cetyl trimethylammonium bromide (CTAB) extraction followed by column clean up and concentration (Genesee Scientific, San Diego, CA). One milligram fresh weight of petiole and midrib tissue yielded $\approx 1$ ng DNA. Each sample was assayed for CLas and citrus dehydrin via qPCR using an ABI 7500 thermocycler (Applied Biosystems, Foster City, CA). Each $25 \mu \mathrm{L}$ qPCR reaction was conducted using $100 \mathrm{ng}$ of DNA template with primers (Stover et al., 2014) specific to 16s ribosomal DNA for CLas detection (Las Long = LL): (USHRL-CL1-L 5' CTTACCAGCCCTTGACATGTATAGG-3' and USHRL-CL1-R 5'-TCCCTATAAAGTACCCAACATCTAGGTAAA-3') or citrus dehydrin (CD-L 5'-TGAGTACGAGCCGAGTGTTG-3' and CD-R 5'-AAAACTTCACCGATCCACCAG-3'). Citrus dehydrin was used as reference control to verify DNA quality and PCR amplification. The master mix consisted of Promega GoTaq qPCR (Madison, WI) with BRYT Green and $0.2 \mu \mathrm{M}$ of each primer using cycle parameters of $2 \mathrm{~min}$ at $95^{\circ} \mathrm{C}$ start, 40 cycles of $15 \mathrm{~s}$ at $95^{\circ} \mathrm{C}, 20 \mathrm{~s}$ at $60{ }^{\circ} \mathrm{C}$, and $20 \mathrm{~s}$ at $72{ }^{\circ} \mathrm{C}$, with a melt curve analysis (to verify product identity). qPCR results analyzed as $\mathrm{Ct}$, and all categorical data were analyzed using the nonparametric
Kruskal-Wallis test (SAS Institute, Cary, $\mathrm{NC}$ ), in which individual tree data are ranked and rankings were analyzed to generate least squares means for each treatment. Statistical significance was then determined through all pairwise $t$ tests at $P \leq 0.05$. From $\mathrm{Ct}$ values, numbers of CLas genomes were calculated per ng DNA extracted, based on previously published laboratory analyses (Stover et al., 2014). Tree size data were analyzed by analysis of variance using PROC GLM (SAS Institute). Data were assessed separately for all imidacloprid-treated trees and separately for the scion/rootstock combinations in which trees had been maintained with and without imidacloprid, except for data presented in Tables 2-4 in which all trees were assessed but scion/rootstock $\times$ imidacloprid treatment were assessed as individual treatments.

The central leader of each tree was clipped to induce flush before assessing colonization by ACP, the vector of HLB. The trees were clipped three times (2 May, 7 July, and 20 Oct. 2011) and 7 to $10 \mathrm{~d}$ after clipping each tree was searched to find one flush shoot with ACP nymphs and/or eggs. Flush was defined as any shoot with developing leaves, which included breaking buds to shoots with expanded, but tender young leaves (Hall and Albrigo, 2007). The first flush shoot with nymphs or eggs, when searching from the top toward the bottom of the plant, was measured from base to tip, placed in a plastic bag, and stored in a cooler with ice packs for transport to the laboratory. If a plant had flush but no nymphs or eggs, then the length of the longest flush shoot was recorded. A tree was omitted during a survey time if no flush was present. Nymphs and eggs were counted on each flush shoot in the laboratory with the aid of dissection microscopes.

Differences in abundances of eggs and nymphs among citrus cultivars, sample dates, and insecticide treatments were tested separately by repeated measures analysis using Poisson regression models (PROC GENMOD, link $=\log$ option, SAS Institute, 2008), with length of flush as the covariate. The interaction between date and citrus cultivar was also analyzed, but was dropped from the model because it was nonsignificant. 
Table 2. Mortality, cropping, and growth for five rootstock/scion combinations. All combinations had 10 trees which received imidacloprid three times per year. All but 'Tango/Kuharske' and 'SugarBelle/Sour Orange' had 10 trees which were not treated. Trees were planted in Aug. 2010 at the U.S. Department of Agriculture research farm (Fort Pierce, FL) under high huanglongbing disease pressure. The first comparison indicates effects of imidacloprid treatment only across rootstock/scion combinations that included trees with and without imidacloprid.

\begin{tabular}{|c|c|c|c|c|c|c|c|}
\hline & \multirow[b]{2}{*}{ Mortality $(\%)$} & \multicolumn{2}{|c|}{ Fruit/tree } & \multirow{2}{*}{$\begin{array}{c}\text { Mottle Feb. } 2015 \\
(\% \text { of leaves })\end{array}$} & \multirow{2}{*}{$\begin{array}{c}\text { Mottle Oct. } 2015 \\
(\% \text { of leaves })\end{array}$} & \multirow{2}{*}{$\begin{array}{l}\text { Change }^{\mathrm{y}} \text { in trunk } \\
\text { diam }(\mathrm{mm})\end{array}$} & \multirow{2}{*}{$\frac{\text { Canopy vol }}{\text { Oct. } 2015\left(\mathrm{~m}^{3}\right)}$} \\
\hline & & Nov. 2014 (no.) & Oct. 2015 (no.) & & & & \\
\hline \multicolumn{8}{|l|}{ Imidacloprid } \\
\hline Not treated & $12 \mathrm{a}^{\mathrm{z}}$ & $8 \mathrm{a}$ & $14 \mathrm{a}$ & $5 \mathrm{a}$ & $13.8 \mathrm{a}$ & $28.2 \mathrm{a}$ & $11.4 \mathrm{a}$ \\
\hline Treated & $18 \mathrm{a}$ & $8 \mathrm{a}$ & $20 \mathrm{a}$ & $6.1 \mathrm{a}$ & $14.1 \mathrm{a}$ & $29.8 \mathrm{a}$ & $12.1 \mathrm{a}$ \\
\hline \multicolumn{8}{|l|}{ Scion/rootstock treatment } \\
\hline Fallglo/Kinkoji-imid & $20 \mathrm{ab}$ & $1.0 \mathrm{de}$ & $31.4 \mathrm{bc}$ & $1.9 \mathrm{c}$ & $2.5 \mathrm{f}$ & $31.5 \mathrm{~b}-\mathrm{e}$ & $9.7 \mathrm{de}$ \\
\hline Fallglo/Kinkoji-no imid & $0 \mathrm{~b}$ & $1.4 \mathrm{c}-\mathrm{e}$ & 8.4 ef & $0.9 \mathrm{c}$ & $6.4 \mathrm{~d}-\mathrm{f}$ & $22.8 \mathrm{f}$ & $5.1 \mathrm{e}$ \\
\hline Hamlin/Cleopatra-imid & $20 \mathrm{ab}$ & $0.6 \mathrm{~b}-\mathrm{e}$ & $18.6 \mathrm{~cd}$ & $5.6 \mathrm{~b}$ & $14.7 \mathrm{~b}-\mathrm{d}$ & $33.2 \mathrm{~b}-\mathrm{d}$ & $13.8 \mathrm{~b}-\mathrm{d}$ \\
\hline Hamlin/Cleopatra-no imid & $30 \mathrm{a}$ & $1.1 \mathrm{~b}-\mathrm{e}$ & $11.6 \mathrm{de}$ & $4.7 \mathrm{~b}$ & $17.1 \mathrm{a}-\mathrm{c}$ & $32.2 \mathrm{~b}-\mathrm{e}$ & $16.3 \mathrm{bc}$ \\
\hline Hamlin/Kinkoji-imid & $20 \mathrm{ab}$ & $6.6 \mathrm{bc}$ & 12.9 ef & $5.1 \mathrm{~b}$ & 4.5 ef & $23.8 \mathrm{ef}$ & $9.4 \mathrm{de}$ \\
\hline Hamlin/Kinkoji-no imid & $10 \mathrm{ab}$ & $2.7 b-d$ & $8.9 \mathrm{~d}-\mathrm{f}$ & $4.6 \mathrm{~b}$ & $9.8 \mathrm{c}-\mathrm{e}$ & $28.5 \mathrm{c}-\mathrm{f}$ & $10.8 \mathrm{c}-\mathrm{e}$ \\
\hline Ruby/Kinkoji-imid & $10 \mathrm{ab}$ & $2.2 \mathrm{~b}$ & $4.6 \mathrm{fg}$ & $11.7 \mathrm{~b}$ & $23.1 \mathrm{a}-\mathrm{c}$ & $25.9 \mathrm{~d}-\mathrm{f}$ & 9 de \\
\hline Ruby/Kinkoji-no imid & $20 \mathrm{ab}$ & $1.3 \mathrm{~b}-\mathrm{d}$ & $2.5 \mathrm{~g}$ & $9.4 \mathrm{~b}$ & $22.9 \mathrm{ab}$ & $23.2 \mathrm{ef}$ & $9.3 \mathrm{de}$ \\
\hline SugarBelle/SourOran-imid & $0 \mathrm{~b}$ & $0 \mathrm{e}$ & $79.8 \mathrm{a}$ & $45.2 \mathrm{a}$ & $29 \mathrm{a}$ & $58 \mathrm{a}$ & $31.1 \mathrm{a}$ \\
\hline Tango/Kuharske-imid & $0 \mathrm{~b}$ & $10 \mathrm{~b}$ & $88.1 \mathrm{a}$ & $8.7 \mathrm{~b}$ & $14.3 \mathrm{a}-\mathrm{c}$ & $45.5 \mathrm{a}$ & $15.7 \mathrm{bc}$ \\
\hline Temple/Cleopatra-imid & $20 \mathrm{ab}$ & $26 \mathrm{a}$ & $35 \mathrm{~b}$ & $5.5 \mathrm{~b}$ & $24.6 \mathrm{a}-\mathrm{c}$ & $35.5 \mathrm{~b}$ & $18.1 \mathrm{~b}$ \\
\hline Temple/Cleopatra-no imid & $0 \mathrm{~b}$ & $29.3 \mathrm{a}$ & $35.4 \mathrm{ab}$ & $6.3 \mathrm{~b}$ & $15.4 \mathrm{a}-\mathrm{c}$ & $34.6 \mathrm{bc}$ & $16.3 \mathrm{bc}$ \\
\hline
\end{tabular}

${ }^{\mathrm{z}}$ Within a column and comparison, means followed by the same letter are not statistically significant at $P=0.05$. Parametric data were analyzed using analysis of variance and means are separated by Duncan's multiple range test. Categorical data were analyzed by Kruskal-Wallis with means separated by $t$ tests of least squares means.

${ }^{y}$ Change in trunk diameter from Apr. 2012 to Oct. 2015.

Table 3. Rootstock/scion combinations in which 10 trees of each received imidacloprid three times per year and 10 were not treated (except 'Sugar Belle/Sour Orange' and 'Tango/Kuharske', which were all treated with imidacloprid). Trees were planted in Aug. 2010, at the U.S. Department of Agriculture research farm (Fort Pierce, FL) under high huanglongbing disease pressure. Trees were monitored on three dates (2 May, 7 July, and 20 Oct. 2011) for abundance of eggs and nymphs of the asian citrus psyllid (Diaphorina citri). No effect of imidacloprid was observed so treated and nontreated trees were pooled for each scion/rootstock (see Table 4).

\begin{tabular}{lccc}
\hline Scion/rootstock & $\mathrm{n}$ & $\begin{array}{c}\text { Mean number of } \\
\text { eggs per flush shoot }\end{array}$ & $\begin{array}{c}\text { Mean number of } \\
\text { nymphs per flush shoot }\end{array}$ \\
\hline Fallglo/Kinkoji & 20 & $20.1 \mathrm{~d}^{\mathrm{z}}$ & $30.0 \mathrm{~cd}$ \\
Hamlin/Cleopatra & 19 & $31.6 \mathrm{~b}-\mathrm{d}$ & $44.5 \mathrm{a}-\mathrm{d}$ \\
Hamlin/Kinkoji & 20 & $55.0 \mathrm{a}$ & $55.3 \mathrm{ab}$ \\
Ruby Red/Kinkoji & 20 & $48.7 \mathrm{ab}$ & $68.3 \mathrm{a}$ \\
Sugar Belle/Sour Orange & 10 & $34.3 \mathrm{a}-\mathrm{d}$ & $30.6 \mathrm{~b}-\mathrm{d}$ \\
Tango/Kuharske & 10 & $26.8 \mathrm{~b}-\mathrm{d}$ & $26.0 \mathrm{~d}$ \\
Temple/Cleopatra & 20 & $26.2 \mathrm{~b}-\mathrm{d}$ & $48.5 \mathrm{a}-\mathrm{c}$ \\
\hline
\end{tabular}

${ }^{\mathrm{z}}$ Within a column, means followed by the same letter are not statistically significant at $P=0.05$.

Table 4. Rootstock/scion combinations in which 10 trees of each received imidacloprid three times per year and 10 remained nontreated (except 'Sugar Belle/Sour Orange' and 'Tango/ Kuharske', which were treated with imidicloprid because there were only 10 total trees of each). Trees were planted in Aug. 2010, at the U.S. Department of Agriculture research farm (Fort Pierce, FL) under high huanglongbing disease pressure. Trees were monitored on three dates (2 May, 7 July, and 20 Oct. 2011) for abundance of eggs and nymphs of Diaphorina citri. Results are for Poisson regression models testing for differences among citrus cultivars, dates, insecticide treatment, and length of flush shoots in abundance of $D$. citri eggs and nymphs.

\begin{tabular}{llrcc}
\hline Life stage & \multicolumn{1}{c}{ Term } & \multicolumn{1}{c}{$\chi^{2}$} & df & $P$ \\
\hline Eggs & Citrus cultivar & 12.9 & 7 & 0.07 \\
& Date & 7.0 & 2 & 0.03 \\
& Insecticide & 0.3 & 1 & 0.61 \\
\multirow{4}{*}{ Nymphs } & Length of flush & 9.2 & 1 & 0.002 \\
& Citrus cultivar & 13.9 & 7 & 0.05 \\
& Date & 16.7 & 2 & $<0.001$ \\
& Insecticide & 1.6 & 1 & 0.20 \\
& Length of flush & 1.4 & 1 & 0.23 \\
\hline
\end{tabular}

Poisson regression models were corrected for over-dispersion when necessary (pscale option, PROC GENMOD, SAS Institute). The
LSMEANS statement was then used, which estimates separation between pairs of means on a log scale (SAS Institute, 2008; Sokal and Rohlf, 1995).

\section{Results and Discussion}

Comparisons of trees where all were treated with imidacloprid. Blotchy mottle: Data collection began after trees had been in the field for 20 months. Initially 'Hamlin/ Kinkoji', 'Hamlin/Cleopatra', 'Ruby Red/ Kinkoji', and 'Temple/Cleopatra' were in the statistical group showing the greatest incidence of blotchy mottle, which is widely accepted as being among the most distinctive and reliable visual symptoms for HLB (Bové, 2006). Blotchy mottle of leaves is a chlorotic pattern, which is not symmetrical on either side of the leaf midrib. 'Fallglo/Kinkoji' was initially in the lowest mottle statistical grouping along with 'Sugar Belle/Sour Orange' and 'Tango/Kuharske' (Fig. 1). 'Fallglo/ Kinkoji' remained in the lowest mottle statistical grouping throughout the experiment, with the exception of November measurements in both 2013 and 2014. 'Ruby Red/ Kinkoji' was in the highest mottle statistical group for 23 of 26 dates. 'Sugar Belle/Sour Orange' increased in mottle symptoms over the course of the trial, was in the highest mottle statistical category for 15 of 26 dates, often showed the most pronounced mottling, and had a significantly greater percentage of leaves showing mottle in Feb. 2015 (45\% of 'Sugar Belle/Sour Orange' leaves displayed mottling vs. $2 \%$ to $12 \%$ in other scion/ rootstocks) and was numerically highest in Oct. 2015 (Table 2).

Shoot color and rugose leaves. Data were collected on new shoot color and rugosity of leaves as additional measures of HLB progression. Marked seasonal variations were observed (data not shown). 'Ruby Red/ Kinkoji' displayed the highest level of yellow shoots and rugose leaves, and the rugose leaf rating for this scion/rootstock was statistically greater than all other scion/rootstocks for the entire study (Table 1). It may be noteworthy that compared with other scion/ rootstocks, rugose leaves were higher in scion/rootstock combinations with grapefruit and sweet orange scions, which also showed marked vigor reduction consistent with their high susceptibility to HLB. Rugose leaves may indicate accumulation of starch in response to occlusion of phloem vessels, and susceptible but tolerant citrus has been reported to maintain transport through phloem even when HLB affected (Fan et al., 2012).

Titer of HLB pathogen. At 20 months in the field, all trees displayed presence of CLas. 'Ruby Red/Kinkoji' and 'Fallglo/Kinkoji' were initially in the statistical grouping with the lowest CLas titers (as indicated by highest $\mathrm{Ct}$ values, Fig. 2) and this continued through Dec. 2012, with other scion/rootstocks occasionally being included in the lowest titer group. However, for 2014-15 means were separated on only two dates and analysis of CLas titer (as Ct) across the entire study period showed no statistical differences between scion/rootstock combinations $(\mathrm{Ct}$ 
means of 21.1-22.6, Table 1). It appeared that different scion/rootstocks can sustain similar levels of CLas with very different effects on tree growth and cropping, as presented below.

Tree growth. Trunk diameter increased steadily in all scion/rootstock combinations. 'Sugar Belle/Sour Orange' began as the smallest trees but showed the greatest growth rate over the course of the experiment and was the largest at the last three dates of assessment, followed by 'Tango/Kuharske' which was often in the same statistical grouping (Fig. 3). Differences between scion/rootstock combinations in canopy volume in Oct. 2015 corresponded closely to increase in trunk diameter. Canopy volume calculations assume a full canopy typical of healthy citrus. After 5 years of growth, the 'Sugar Belle/Sour Orange', 'Tango/ Kuharske', and 'Temple/Cleo' had full canopies but with size somewhat reduced compared with expectations for healthy trees, based on grower reports. After 5 years, the 'Hamlin/Cleo' and 'Hamlin/Kinkoji' trees were composed of a few branches rather than a spheroid of foliage, and so the canopy volume data are somewhat misleading, as these trees were more similar in size to 2-year-old healthy sweet orange trees.

With three scion cultivars on one rootstock and two scions on another, we can make some comparisons directly between scions. For scions on 'Kinkoji' that were treated with imidacloprid, 'Fallglo' showed significantly greater increase in stem diameter than 'Hamlin', even though 'Fallglo' is considered much less vigorous than 'Hamlin' in the absence of HLB. For scions on 'Cleopatra', 'Temple', and 'Hamlin' had an equivalent increase in stem diameter, even though 'Temple' is considered less vigorous than 'Hamlin' in the absence of HLB.

Mortality and cropping. Mortality was not different among the scion/rootstock combinations (Table 2). The percentage of trees carrying fruit and the number of fruit per tree were different between scion/rootstocks (Table 2). In Nov. 2014, 'Ruby Red/Kinkoji', 'Temple/Cleopatra', 'Hamlin/Kinkoji', and 'Tango/Kuharske' were in the statistical grouping with the highest proportion of trees carrying fruit, and 'Temple/Cleopatra' had the greatest number of fruit per tree. 'Sugar Belle/Sour Orange' and 'Fallglo/Kinkoji' were in the statistical grouping with the lowest proportion of trees carrying fruit and, along with 'Hamlin/Cleopatra', were also in the statistical grouping with the lowest number of fruit per tree. All scion/rootstocks displayed increased cropping in the next season, and all scion/rootstocks had greater than 20 fruit/tree except those with sweet orange or grapefruit as a scion (Oct. 2015, Table 2). All surviving trees continued to increase in trunk diameter, with 'Sugar Belle/ Sour Orange' and 'Tango/Kuharske' in the statistical grouping with the largest trunk diameter (Fig. 3), greatest growth rate, and highest fruit number per tree in Oct. 2015 (Table 2). Although $100 \%$ of the trees were
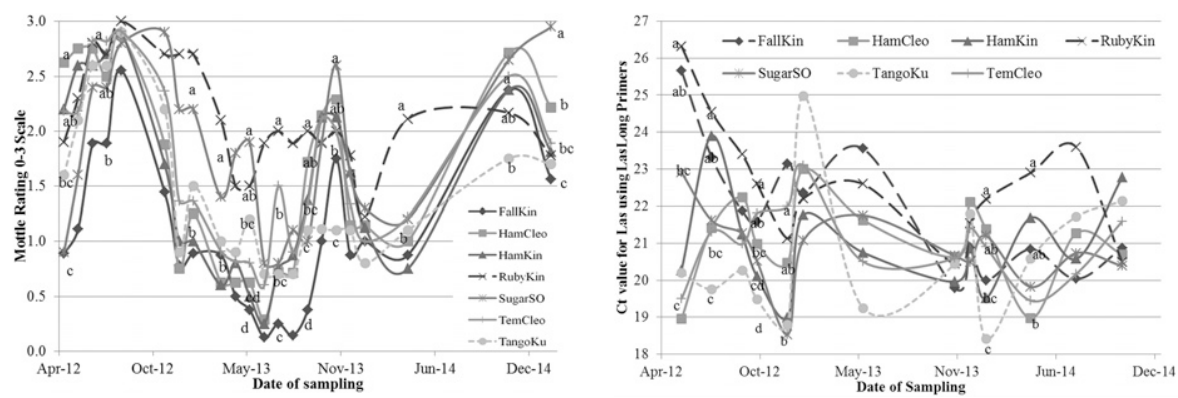

Fig. 1. Blotchy mottle ratings of leaves (the chlorotic pattern is not symmetrical on either side of the leaf midrib), which is one of the most reliable visual symptoms of huanglongbing (HLB). Mottle was rated periodically on a 3 -point scale $(0=$ healthy, $1=$ pale mottling, $2=$ mottle but symmetric, and $3=$ blotchy mottle) by assessing the most symptomatic leaves on scion/rootstock combinations grown in high HLB pressure on a site in Fort Pierce, FL, planted on Aug. 2010. All trees received imidacloprid three times per year. FallKin $=$ 'Fallglo' on 'Kinkoji' rootstock; HamCleo = 'Hamlin' sweet orange on 'Cleopatra' rootstock; HamKin = 'Hamlin' sweet orange on 'Kinkoji' rootstock; RubyKin = 'Ruby Red' grapefruit on 'Kinkoji' rootstock; SugarSO = 'Sugar Belle' on 'Sour Orange' rootstock; TangoKu $=$ 'Tango' on 'Kuharske' rootstock; and $\mathrm{TemCleo}=$ 'Temple' on 'Cleopatra' rootstock. Within a sampling date, means marked by the same letter are not significantly different at $P=0.05$ by $t$ tests within Kruskal-Wallis analysis.

infected with CLas for several years, most continued to develop, though 'Ruby Red/ Kinkoji' trees were in severe decline, noted by thin canopies. Among scions on 'Kinkoji', 'Fallglo' showed significantly greater cropping than 'Hamlin' and 'Ruby Red' in 2015. Among scions on 'Cleopatra', 'Temple' showed significantly greater cropping than 'Hamlin' in 2014 and 2015.

Effect of rootstock with 'Hamlin'. 'Hamlin' sweet orange was planted on both 'Kinkoji' and 'Cleopatra' rootstocks. With so many sample points, it is not surprising that differences were occasionally observed between 'Hamlin' trees on the two rootstocks (Table 3). However, most differences were negligible over the course of the experiment (Tables 1-4; Figs. 1-4).

Effect of imidacloprid on scion/rootstock combination trees. The CLas titers (assessed as $\mathrm{Ct}$ ) were initially different between treated and nontreated trees only for 'Ruby Red/ Kinkoji', but no further differences were observed over time (Fig. 4). Overall tree growth was affected by imidacloprid only in 'Fallglo/Kinkoji', with greater growth in the treated trees (Table 2). 'Ruby Red/Kinkoji' showed early suppression of growth when no imidacloprid was applied (data not shown). No effects were observed on mortality or fruit production from imidacloprid applications, except that 'Fallglo/Kinkoji' showed a significant reduction in fruit production in nontreated vs. imidacloprid-treated trees (Table 2). There was negligible effect of
Fig. 2. Mean titers of the huanglongbing (HLB) pathogen, expressed as cycle threshold $(\mathrm{Ct})$ from quantitative polymerase chain reaction (higher $\mathrm{Ct}$ is lower titer) in scion/rootstock combinations grown under high HLB pressure on a site in Fort Pierce, FL, planted on Aug. 2010. All trees received imidacloprid three times per year. FallKin = 'Fallglo' on 'Kinkoji' rootstock; HamCleo = 'Hamlin' sweet orange on 'Cleopatra' rootstock; HamKin = 'Hamlin' sweet orange on 'Kinkoji' rootstock; RubyKin = 'Ruby Red' grapefruit on 'Kinkoji' rootstock; SugarSO = 'Sugar Belle' on 'Sour Orange' rootstock; TangoKu = 'Tango' on 'Kuharske' rootstock; and TemCleo $=$ 'Temple' on 'Cleopatra' rootstock. Within a date, means marked by the same letter are not significantly different at $P=0.05$ by least squares-mean analysis from Kruskal-Wallis. No mean separation letters are presented for dates, in which no $\mathrm{Ct}$ differences were observed at $P=0.05$. One milligram fresh weight of petiole and midrib tissue yielded $\approx 1$ ng DNA. The following are calculated numbers of Candidatus Liberibacter asiaticus (CLas) genomes per ng DNA extracted: $\mathrm{Ct}$ of $19=11,575$ CLas genomes, Ct of $21=3,290$ CLas genomes, $\mathrm{Ct}$ of $23=937$ CLas genomes, $\mathrm{Ct}$ of $25=266$ CLas genomes, and $\mathrm{Ct}$ of $27=75$ CLas genomes.

imidacloprid treatment on mottle or yellow shoot ratings, with statistical significance only at two of 26 dates (data not shown). Rugose leaf ratings were never statistically influenced by imidacloprid treatment (data not shown). Trees in this trial were under extraordinary ACP pressure with no control on adjoining trees just a few meters away, making it likely that ACP feeding was routine even on imidacloprid-treated trees. In fact, ACP colonization was not influenced by imidacloprid treatments (Table 4), suggesting poor efficacy of this treatment against ACP in this experiment, at least in 2012 when ACP data were collected. Previous research in relatively small research plots surrounded by citrus under minimal ACP control showed that intensive insecticide programs including imidacloprid treatments were ineffective for preventing HLB from developing in young trees (Hall et al., 2013a).

Colonization by $A C P$. Egg densities varied according to the length of flush shoots (most abundant on short shoots) and among sample dates (data not shown). Treatment with insecticide did not influence the abundance of eggs (Table 4). Egg abundance did not differ significantly among the citrus cultivars at $P=0.05$, but was significant at $P=0.10$ (Table 4). Sample date and cultivar, 


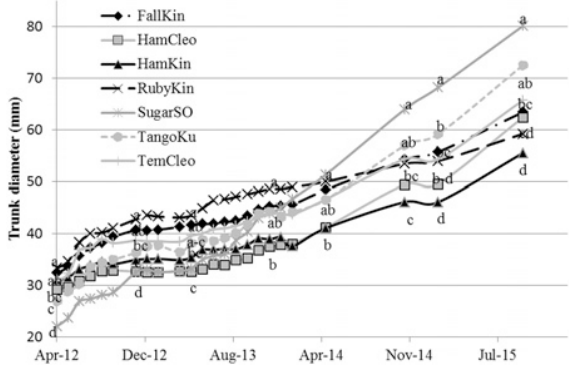

Fig. 3. Mean trunk diameters for scion/rootstock combinations grown under high huanglongbing pressure on a site in Fort Pierce, FL, planted on Aug. 2010. All trees received imidacloprid three times per year. FallKin = 'Fallglo' on 'Kinkoji' rootstock; HamCleo = 'Hamlin' sweet orange on 'Cleopatra' rootstock; HamKin = 'Hamlin' sweet orange on 'Kinkoji' rootstock; RubyKin = 'Ruby Red' grapefruit on 'Kinkoji' rootstock; SugarSO = 'Sugar Belle' on 'Sour Orange' rootstock; TangoKu = 'Tango' on 'Kuharske' rootstock; and TemCleo $=$ 'Temple' on 'Cleopatra' rootstock. Within a date, means marked by the same letter are not significantly different at $P=0.05$ by Duncan's multiple range test. No mean separation letters are presented for dates in which no differences were observed at $P=0.05$.

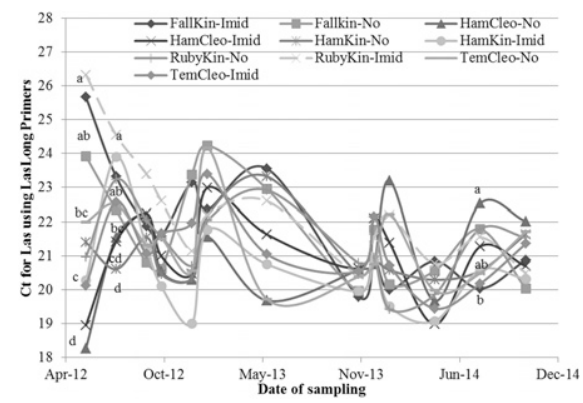

Fig. 4. Mean titers of the huanglongbing (HLB) pathogen, expressed as cycle threshold $(\mathrm{Ct})$ from quantitative polymerase chain reaction (higher $\mathrm{Ct}$ is lower titer) in scion/rootstock combinations grown under high HLB pressure on a site in Fort Pierce, FL. All trees received imidacloprid three times per year. FallKin $=$ 'Fallglo' on 'Kinkoji' rootstock; HamCleo = 'Hamlin' sweet orange on 'Cleopatra' rootstock; HamKin = 'Hamlin' sweet orange on 'Kinkoji' rootstock; RubyKin = 'Ruby Red' grapefruit on 'Kinkoji' rootstock; SugarSO = 'Sugar Belle' on 'Sour Orange' rootstock; TangoKu = 'Tango' on 'Kuharske' rootstock; and $\mathrm{TemCleo}=$ 'Temple' on 'Cleopatra' rootstock. Comparison of trees receiving imidacloprid (legend entry followed by Imid) three times per year vs. untreated (legend entry followed by No). Within a date, means marked by the same letter are not significantly different at $P=0.05$ by LS-mean analysis from KruskalWallis. No mean separation letters are presented for dates in which no $\mathrm{Ct}$ differences were observed at $P=0.05$ for the same scion/ rootstock combination with and without imidacloprid.

but not insecticide use or length of flush, were significant sources of variation in nymph abundance (Table 4). 'Hamlin/
Kinkoji' and 'Ruby Red/Kinkoji' were in the highest abundance statistical grouping for eggs and nymphs, while 'Fallglo/Kinkoji', 'Sugar Belle/Sour Orange', and 'Tango/ Kuharske' were consistently in the lowest abundance grouping (Table 3). For scions on 'Kinkoji', 'Fallglo' showed significantly lower abundance of eggs and nymphs than 'Hamlin' or 'Ruby Red'. For scions on 'Cleopatra', 'Temple' had significantly higher abundance of eggs and nymphs than 'Hamlin'. However, observed infestation levels of eggs and nymphs were relatively high on each of the seven scion/rootstocks as compared with infestation levels that have been reported on many other genotypes within the Rutaceae (Westbrook et al., 2011). Tolerance to HLB was, therefore, likely due to tolerance to the pathogen and not the vector.

Comparisons to other reports. In an early assessment of HLB incidence and pathogen titer in commercial Florida groves exposed to HLB when mature, Temple, Fallglo, and grapefruit cultivars had lower levels of initial CLas titer and HLB mottle symptoms compared with Minneola and were somewhat lower than sweet orange (Stover and McCollum, 2011). Anecdotal reports continue to support a useful level of HLB tolerance in 'Temple' (E.W. Stover, unpublished data) and 'Fallglo' (T.G. McCollum, personal communication), but Florida grapefruit orchards are now generally in severe decline. Although 'Minneola', which is a parent of 'Sugar Belle', was among the worst cultivars for initial HLB symptoms, it is now widely viewed as having useful HLB tolerance with adequate canopy health and reasonable production of healthy fruit (E.W. Stover, unpublished data). It must be concluded that initial CLas titer and symptom expression may provide little insight into response after the disease becomes established.

At the time this experiment was started, there was little evidence that rootstock would have a meaningful effect on HLB development. There are now several anecdotal reports of trees on certain rootstocks showing greater HLB tolerance (Wells et al., 2013) and even discussions of specific scion/rootstock combinations that fare better in the presence of HLB (Castle et al., 2015b). This underscores the importance of interpreting most of the results of this study within the context of scion/rootstock combinations.

There are several observations that permit cautious optimism that the tolerance we observed in mandarin/rootstock combinations may reflect greater tolerance within the mandarin scion. The mandarin hybrid/ rootstock combinations, but not sweet orange/ rootstock or grapefruit/rootstock, in this trial showed acceptable health and a reasonable level of cropping. A recent extension publication (Castle et al., 2015a), which indicates that some citrus rootstock are tolerant to HLB, cautions that such ratings are based only on observations and are both speculative and subject to revision, and the rootstocks proposed to be tolerant are all new rootstocks and not the rootstocks we used in this study. The few published reports on rootstock effects on HLB vary, but with little strong evidence of rootstock effects. In analysis of overall health of trees where HLB is endemic, differences observed are inconsistent between trees on a given rootstock (Castle et al., 2015b). Some previous reports show little or no rootstock effect on growth, HLB symptoms, and CLas titer (Albrecht et al., 2012; Stover et al., 2014), while in some cases, trees that were older when infected continued to show rootstock effects on yield following CLas infection despite marked declines over time (Albrecht et al., 2012). In the Albrecht et al. (2012) study, all of the rootstocks studied here ['Cleopatra', 'Carrizo' ('Kuharske' is a selection of 'Carrizo'), 'Kinkoji', and 'Sour Orange'] were included with sweet orange as the scion. Of 78 pairwise comparisons for data similar to parameters reported in this study, only five were statistically significantly different. So far, published data indicate only modest effects of rootstock on scions following CLas infection, which is consistent with the negligible differences observed between 'Hamlin/ Kinkoji' and 'Hamlin/Cleopatra' in this study.

\section{Conclusions}

All trees had high CLas (low Ct) by 20 months after planting. Initial CLas was somewhat lower (higher Ct) in 'Ruby Red/ Kinkoji' and 'Fallglo/Kinkoji', but differences were short lived. 'Ruby Red/Kinkoji' showed lower CLas titer (higher $\mathrm{Ct}$ ) from imidacloprid treatment but only at the first time point, and only 'Fallglo/Kinkoji' showed any positive effect of imidacloprid on tree trunk diameter or fruit production. Although there were significant differences among the scion/rootstock combinations with respect to ACP colonization, all were susceptible to sizeable infestations and observed differences were relatively small, suggesting observed differences in HLB effects were related to tolerance to CLas, not resistance to ACP.

The greatest growth rates and canopy volumes were observed in 'Sugar Belle/Sour Orange', 'Tango/Kuharske', and 'Temple/ Cleopatra' and the slowest growth rates and canopy volumes in 'Ruby Red/Kinkoji'. Percentage of leaves showing mottle was highest in 'Sugar Belle/Sour Orange' even though it displayed the greatest growth rate.

Despite early HLB development, trees continued to grow and all scion/rootstocks, except 'Hamlin/Kinkoji', 'Hamlin/Cleopatra', and 'Ruby Red/Kinkoji' displayed continued development into bearing. However, development was less than would be expected for healthy trees. It remains to be seen whether the HLB tolerance in some scion/rootstock combinations permit reasonable production of fruit of commercial quality, but it is promising that several mandarin hybrid/rootstock combinations displayed markedly greater growth and cropping 
compared with sweet orange/rootstock and grapefruit/rootstock combinations under very high HLB pressure. Larger replicated comparisons of scion cultivars on a common rootstock are underway. It is noteworthy that the most pronounced HLB symptoms and higher early pathogen titer, which are the two criteria most widely used in assessing HLB resistance, were not associated with the greatest suppression of growth and cropping, and focus on early symptomatic traits may obscure important disease tolerance.

\section{Literature Cited}

Albrecht, U., G. McCollum, and K.D. Bowman. 2012. Influence of rootstock variety on Huanglongbing disease development in field-grown sweet orange (Citrus sinensis [L.] Osbeck) trees. Sci. Hort. 138:210-220.

Bové, J.M. 2006. Huanglongbing: A destructive, newly-emerging, century-old disease of citrus. J. Plant Pathol. 88:7-37.

Castle, W.S., K.D. Bowman, J.W. Grosser, S.H Futch, and J.H. Graham. 2015a. Florida citrus rootstock selection guide. 3rd ed. University of Florida Extension Publication SP248. Nov. 2015. <http://edis.ifas.ufl.edu/hs1260>.

Castle, B., J. Grosser, K. Bowman, and E. Stover. 2015b. An HLB-tolerant citrus rootstock: What exactly does that mean? Citrus Ind. 2015:16-19.

Fan, J., C. Chen, Q. Yu, A. Khalaf, D.S. Achor, R.H. Brlansky, G.A. Moore, Z.-G. Li, and F.G. Gmitter, Jr. 2012. Comparative transcriptional and anatomical analyses of tolerant rough lemon and susceptible sweet orange in response to 'Candidatus Liberibacter asiaticus' infection. Mol. Plant Microbe Interact. 25:13961407.

Hall, D.G. and L.G. Albrigo. 2007. Estimating the relative abundance of flush shoots in citrus with implications on monitoring insects associated with flush. HortScience 42:364-368.

Hall, D.G., T.R. Gottwald, E. Stover, and G.A.C. Beattie. 2013a. Evaluation of management programs for protecting young citrus plantings from huanglongbing. HortScience 48:330-337.

Hall, D.G., M.L. Richardson, E.-D. Ammar, and S.E. Halbert. 2013b. Asian citrus psyllid, Diaphorina citri (Hemiptera: Psyllidae), vector of citrus huanglongbing disease. Entomol. Expt. Appl. 146:207-223.

NASS. 2015. Florida citrus statistics, 2013-2014. Sept. 2015. <http://www.nass.usda.gov/Statistics by_State/Florida/Publications/Citrus/fcs/201314/fcs1314.pdf>.

SAS Institute. 2008. Statistical analysis system, version 9.2. SAS Inst., Cary, NC.

Singerman, A. and P. Useche. 2015. Impact of citrus greening on citrus operations in Florida. University of Florida, IFAS, Citrus Research and Education Center, Lake Alfred, FL. Nov. 2015. <http://www.crec.ifas.ufl.edu/extension/ economics/pdf/Impact $\% 20$ Citrus $\% 20$ Greening $\%$ 20web.pdf $>$.

Sokal, R.R. and F.J. Rohlf. 1995. Biometry: The principles and practice of statistics in biological research. 3rd ed. Freeman, New York, NY.
Spann, T.M., R.A. Atwood, M.M. Dewdney, R.C. Ebel, R. Ehsani, G. England, S.H. Futch, T. Gaver, T. Hurner, C. Oswalt, M.E. Rogers, F.M. Roka, M.A. Ritenour, M. Zekri, B.J. Boman, K.-R. Chung, M.D. Danyluk, R. GoodrichSchneider, K.T. Morgan, R.A. Morris, R.P. Muraro, P. Roberts, R.E. Rouse, A.W. Schumann, P.A. Stansly, and L.L. Stelinsk. 2014. IFAS guidance for huanglongbing (greening) management. Jan. 2016. <https://edis.ifas.ufl.edu/hs1165>.

Stover, E. and G. McCollum. 2011. Incidence and severity of huanglongbing and Candidatus Liberibacter asiaticus titer among field-infected citrus cultivars. HortScience 46:1344-1348.

Stover, E., T.G. McCollum, R. Driggers, R. Lee, R. Shatters, Jr., Y.P. Duan, M. Ritenour, J.X Chaparro, and D.G. Hall. 2015. Resistance and tolerance to Huanglongbing in citrus. Acta Hort. 1065:899-903.

Stover, E., G. McCollum, J. Ramos, and R.G. Shatters, Jr. 2014. Growth, health and Liberibacter asiaticus titer in diverse citrus scions on mandarin versus trifoliate hybrid rootstocks in a field planting with severe huanglongbing. Proc. Fla. State Hort. Soc. 127:53-59.

Wells, R.H., J. Grosser, and F. Gmitter. 2013. UF researchers identify citrus cultivars that show promise in battle against greening. UF News. Nov. 2015. <http://news.ufl.edu/2013/09/25/ citrus-rootstock/ $>$.

Westbrook, C.J., D.G. Hall, E.W. Stover, Y.P. Duan, and R.F. Lee. 2011. Colonization of Citrus and Citrus-related germplasm by Diaphorina citri (Hemiptera: Psyllidae). HortScience 46:997-1005. 